\title{
REVERSAL OF DIURNAL VARIATION IN RENAL FUNCTION IN CASES OF CIRRHOSIS WITH ASCITES ${ }^{1,2}$
}

\author{
By RICHARD A. JONES, GERALD O. MCDONALD, AND JULES H. LAST \\ (From the Department of Experimental Medicine, Northwestern University Medical School, \\ and the Veterans Administration Hospital, Hines, Illinois)
}

(Submitted for publication October 4, 1951; accepted January 8, 1952)

The mechanism for control of diurnal rhythm of water and electrolyte excretion remains obscure, though the fact that such a cycle occurs was reported by Quincke (1) in 1877 who pointed out that urinary output was appreciably higher during the day in contrast to night. Campbell and Webster $(2,3)$ observed that the excretion of chlorides and urea was also higher during the day, though creatinine excretion remained more or less at the same level. Subsequent studies (Table I) by Kleitman (4), Simpson (5, 6), Norn (7), Manchester (8), Gerritzen (9), Brod (10), and Sirota, Baldwin, and Villarreal (11) confirmed the observations that urine flow and excretion of certain electrolytes decreased during the hours of deepest sleep in normal individuals.

This rhythm was not reversed when normal subjects slept in the daytime and took food and worked at night as reported by Campbell and Webster $(2,3)$, and confirmed in studies of a night watchman by Jores (12). Gerritzen (13) studied the effect of exposure of four subjects to artificial daylight during the night, and darkness during the day. In three subjects duplication of the rhythm in water and chloride excretion resulted, with two maxima occurring at noon and at midnight. In the fourth subject the rhythm was completely reversed. Borst and de Vries (14) have pointed out the difficulty in evaluating the effect of daylight and of waking on diurnal rhythm, though in some of their subjects the response to the stimulus of daylight was prompt. Jores (12)

1 This investigation was supported by research grants from the Veterans Administration and the National Heart Institute, of the National Institutes of Health, U. S. Public Health Service.

2 Reviewed in the Veterans Administration and published with the approval of the Chief Medical Director. The statements and conclusions published by the authors are the result of their own study and do not necessarily reflect the opinion or policy of the Veterans Administration. reported the relative difficulty in reversing a rhythm by a reversal of routine, and this was further supported by Joslings' (15) observation that a subject on a boat going from east to west showed a peak urinary excretion one hour earlier every day, the peak remaining at the same hour on local time. Addis and associates (16) reported nocturnal depression of endogenous creatinine clearances.

On the basis of $U / P$ inulin ratios and creatinine clearance data, Sirota, Baldwin, and Villarreal (11) attributed the decrease in urine flow during sleep almost wholly to water reabsorption. The mechanisms of increased tubular reabsorption of water at night were not elucidated and significant diurnal variations in effective renal plasma flow were not noted (11).

Reports of a reversal of renal function (Table II) began with Wilson's (17) observation that the day and night rates of excretion of water and solids were approximately the same in the presence of debility, and especially so in cardiac or renal disease. Quincke (18) confirmed these observations several years later, noting that patients with heart or kidney disease often had a peak of diuresis during the night. Fishberg (19) attributed the nocturnal increase in urine flow in patients with nephritis and congestive heart failure to decreased renal venous pressure and increased cardiac output in the prone position. Subsequent work by Brod and Fejfar (20) and by Baldwin, Sirota, and Villarreal (21), employing clearance techniques, revealed an increased glomerular filtration rate and decreased tubular reabsorption of water during the hours of sleep in patients with congestive heart failure. In the absence of peripheral edema, or during active diuresis, no reversal of the diurnal pattern was observed (21). According to Brod and Fejfar (20), nocturia was not associated with an increase in cardiac output. Since nocturnal diuresis was always associated with an increase in 
TABLE I

Studies of diurnal variations of renal function in normal individuals

\begin{tabular}{|c|c|c|c|}
\hline \multirow{2}{*}{ Invest1 gator } & \multicolumn{3}{|c|}{ Renal Functions Studied } \\
\hline & No Diurnal Chango & $\begin{array}{c}\text { Hocturnal } \\
\text { Depression Oserved }\end{array}$ & Attributed to \\
\hline $\operatorname{luthels~}^{(1)}$ & - & Urine $f l o w$ & \\
\hline${ }_{\text {Campbal1 }}^{(2,3)}$ & Greatinine excretion & $\begin{array}{l}\text { Urine flow, excr. urea, } \\
\text { Cl. }\end{array}$ & - \\
\hline $\begin{array}{c}\text { Kloitman } \\
(1923) \\
\end{array}$ & $\begin{array}{l}\text { Nitrogen or creatinine } \\
\text { excr. }\end{array}$ & $\begin{array}{l}\text { Urine rlow, excr. of } \\
\text { phosphates, acids and } \mathrm{Cl}\end{array}$ & $\begin{array}{l}\text { Decr. blood } \\
\text { pressure. }\end{array}$ \\
\hline$\underset{(1924,1926)}{(5,6)}$ & & $\begin{array}{l}\text { Urine flow, phosphate } \\
\text { and Cl. excr., urine } \\
\text { pH. }\end{array}$ & $\begin{array}{l}\text { Acidosis of sleep } \\
\text { with intracellutar } \\
\text { shift of chloride } \\
\text { and water. }\end{array}$ \\
\hline $\begin{array}{l}\operatorname{Norn} \\
(1929)^{\prime}\end{array}$ & & $\begin{array}{l}\text { Urine rlow, excr. of } \\
\text { Na., K., Cl. }\end{array}$ & Diminished activity \\
\hline Yanchester $^{(1933) *}$ & $\begin{array}{l}\text { Excr. of Ca., } \text { Yg., } \\
\text { (Data on phosphate, } \\
\text { sulfate, amonia exer. } \\
\text { \& titratable acidity } \\
\text { were equivocal). }\end{array}$ & $\begin{array}{l}\text { Urine flow, excr. of } \\
\mathrm{Na}_{.}, \overline{\mathrm{K}}_{\bullet}, \mathrm{CI}\end{array}$ & Belated to sleep \\
\hline $\begin{array}{l}\text { Cerritzen } \\
(1940)\end{array}$ & & $\begin{array}{l}\text { Urine flow, excr. urea, } \\
\text { Cl. }\end{array}$ & $\begin{array}{l}\text { Rhythmic organ } \\
\text { function and posi- } \\
\text { tion change. }\end{array}$ \\
\hline Brod $(10)$ & & $\begin{array}{l}\text { Urine flow, endog. } \\
\text { creat. clear. }\end{array}$ & 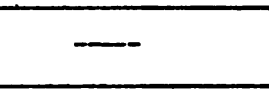 \\
\hline $\begin{array}{l}\text { (11) } \\
\text { Sirota } \\
(1950)\end{array}$ & PAH clear. & $\begin{array}{l}\text { Urine flow, inulin } \\
\text { clear. }\end{array}$ & $\begin{array}{l}\text { Variations in tub- } \\
\text { ular reabsorption. }\end{array}$ \\
\hline $\begin{array}{l}\text { Borat } \\
(1950)\end{array}$ & $\begin{array}{l}\text { Bxcr. urea, creat } \\
\text { inine. }\end{array}$ & $\begin{array}{l}\text { Urine } \mathrm{nom}, \text { excr. } \mathrm{Na}, \text {, } \\
\mathrm{Cl}, \mathrm{K} .\end{array}$ & $\begin{array}{l}\text { Variations in tub } \\
\text { ular reabsorption. }\end{array}$ \\
\hline $\begin{array}{l}\text { Idis } \\
\text { (1951) }\end{array}$ & ${ }_{2}$ & Endog. creat. clear. & $\begin{array}{l}\text { Relaxation of vasc. } \\
\text { tension with drop } \\
\text { in filt. press. }\end{array}$ \\
\hline
\end{tabular}

* Data on tro epileptic children on graded activity.

renal blood flow and a decrease in filtration fraction, they attributed the nocturia to the increased flow of blood to the kidneys during the period of complete rest.

Previous reports of renal function in cirrhosis (Table III) are conflicting. Leslie, Johnson, and Ralli (22) reported a depression of renal hemodynamics in cirrhosis. They observed higher rates of glomerular filtration and effective renal plasma flow in patients without ascites or during active diuresis than in the presence of actively reaccumulating ascites. Patek and associates (23), and more recently Goodyer, Relman, Lawrason, and Epstein (24) observed that mean glomerular filtration rates and effective renal plasma flows were within normal limits in this disease. Farns- worth and Krakusin (25) showed that the electrolyte excretion in patients with hepatic cirrhosis and ascites resembled that seen in cardiac failure. More recently, Goldman (26) observed a nocturnal diuresis of water and sodium in patients with congestive heart failure, glomerulonephritis, and cirrhosis of the liver. The nocturia and increased nocturnal chloride excretion in patients with cirrhosis reported by Smits (27) was attributed by Borst and de Vries (14) to semi-recumbent position at night.

During the course of water partition studies in cirrhotics with ascites, at which time renal clearances were performed, a reversal of diurnal rhythm in renal function was noted. An abstract of these observations has been published elsewhere (28). 
TABLE It

Studies of diurnal variations of renal function in certain pathologic states

\begin{tabular}{|c|c|c|c|c|}
\hline \multirow{2}{*}{ Invertigator } & \multirow{2}{*}{$\begin{array}{l}\text { Pathologic } \\
\text { State }\end{array}$} & \multicolumn{3}{|c|}{ Renal Function Variation } \\
\hline & & Studied & Observed & Attributed to \\
\hline (1893) $^{\text {Quincke }^{(18)}}$ & $\begin{array}{l}\text { Nephrit1s } \\
\text { Congestive heart } \\
\text { failure }\end{array}$ & Water excretion & Nocturia & \\
\hline$\underset{(1889)}{\operatorname{milscx}}(17)$ & $\begin{array}{l}\text { Nephritis } \\
\text { Congestive heart } \\
\text { failure }\end{array}$ & $\begin{array}{l}\text { Water and solid } \\
\text { excretion }\end{array}$ & $\begin{array}{l}\text { Nocturia, incr. } \\
\text { solid excr. }\end{array}$ & \\
\hline Plohberg $_{\text {(1989) }}^{(19)}$ & $\begin{array}{l}\text { Nephritis } \\
\text { Congestive heart } \\
\text { failure }\end{array}$ & $\begin{array}{l}\text { Water and electro- } \\
\text { lyte excr. }\end{array}$ & Nocturis & $\begin{array}{l}\text { lecr. renal ven- } \\
\text { ous press., incr. } \\
\text { cardiac out put in } \\
\text { prone pos. }\end{array}$ \\
\hline \multirow{2}{*}{$\begin{array}{r}\text { Brod }(10) \\
(1946)\end{array}$} & Glomerulonephritis & \multirow[t]{2}{*}{ Creatinine clear. } & $\begin{array}{l}\text { Nocturia, decr. } \\
\mathrm{H}_{2} \mathrm{O} \text { reabsorb. }\end{array}$ & \\
\hline & $\begin{array}{l}\text { Congestive heart } \\
\text { failure }\end{array}$ & & $\begin{array}{l}\text { Nocturia, incr. } \\
\text { GFR, decr. } \mathrm{H}_{2} \mathrm{O} \\
\text { reabsorb. }\end{array}$ & \\
\hline \multirow{2}{*}{$\begin{array}{l}\text { Baldwin (2l) } \\
\text { ot al } \\
(1950)\end{array}$} & \multirow{2}{*}{$\begin{array}{l}\text { Congestive } \\
\text { heart } \\
\text { failure }\end{array}$} & \multirow{2}{*}{$\begin{array}{l}\text { Invlin and creat- } \\
\text { Inine clear., U/P } \\
\text { ratios, excr. Na. }\end{array}$} & $\begin{array}{l}\text { Nocturia, incr. } \\
\text { GFR, incr. Na } \\
\text { excr. }\end{array}$ & $\begin{array}{l}\text { Nocturia not re- } \\
\text { lated to level } \\
\text { of GFR. }\end{array}$ \\
\hline & & & $\begin{array}{l}\text { Decr. urine flow, } \\
\text { decr. GFR, decr. } \\
\text { Na excr. (at } \\
\text { night) }\end{array}$ & \\
\hline $\begin{array}{l}\text { Brod \& (20) } \\
\text { Polffar } \\
(1950)\end{array}$ & $\begin{array}{l}\text { Congestive heart } \\
\text { failure }\end{array}$ & $\begin{array}{l}\text { Inulin, PAH clear. } \\
\text { cardiac out put. }\end{array}$ & $\begin{array}{l}\text { Nocturia, incr. } \\
\text { GFR, incr. ERPF, } \\
\text { decr. F.F., No } \\
\text { change in cardiac } \\
\text { out put }\end{array}$ & $\begin{array}{l}\text { Incr of blood } \\
\text { flow to kidneys } \\
\text { with dininished } \\
\text { activity. }\end{array}$ \\
\hline $\begin{array}{l}\text { sutts }(27) \\
1950)\end{array}$ & $\begin{array}{l}\text { Cirrhosis } \\
\text { Congestive heart } \\
\text { failure }\end{array}$ & $\begin{array}{l}\text { Water and } \mathrm{Cl} \\
\text { excr. }\end{array}$ & $\begin{array}{l}\text { Nocturia, incr. } \\
\text { Cl excr. }\end{array}$ & $\begin{array}{l}\text { semi-recumbent } \\
\text { position at } \\
\text { night. }\end{array}$ \\
\hline$\underset{(1951)}{\operatorname{Coldman}}(26)$ & $\begin{array}{l}\text { Congestive heart } \\
\text { failure } \\
\text { Glomerulonephritis } \\
\text { Cirrhosis }\end{array}$ & $\mathrm{Na}, \mathrm{K}, \mathrm{H}_{2} \mathrm{O}$ excr. & $\begin{array}{l}\text { Nocturia, incr. } \\
\text { Na excr., No } \\
\text { change K excr. }\end{array}$ & $\begin{array}{l}\text { Unknown humoral } \\
\text { factors }\end{array}$ \\
\hline
\end{tabular}

The present paper presents further data on diurnal variations in renal hemodynamics in normal subjects and cases of cirrhosis.

\section{METHODS}

The diagnosis of Laennec's cirrhosis was made by the usual clinical and laboratory methods in the patients studied. Each of these patients had been hospitalized one or more times previously at Hines Veterans Administration Hospital, at which time the diagnosis of cirrhosis had been established. Patients selected for this study manifested no clinical evidence of cardiovascular renal disease as judged by past history, physical findings, electrocardiographic and laboratory findings. This group had in common the presence of reaccumulating ascites (Table IV), which required repeated hospital admissions and paracenteses. Normal subjects were healthy adult males who were either awaiting elective surgery or convalescing from minor surgical procedures. The subjects were allowed food and liquid ad libitum but were kept recumbent in bed throughout the experimental procedure. No pre- liminary hydration was employed. The clearance of inulin was used to estimate glomerular filtration rate (GFR) and that of para-aminohippurate to estimate effective renal plasma flow (ERPF). A priming injection of inulin and para-aminohippurate was followed by a sustaining infusion delivered at a constant rate by a pump over a 24 hour period. All solutions were infused into an antecubital vein by means of nylon tubing which permitted the patient to move about freely in bed without fear of subcutaneous extravasation of the infusate (29). Urine samples were collected by an indwelling multi-eyed catheter. At the conclusion of each clearance period, the bladder was rinsed with $60 \mathrm{cc}$. of saline to insure quantitative recovery of all urine. The spot clearance periods were 20 to 30 minutes in duration and in addition a concurrent 24 hour period was run on each patient. Two consecutive periods were run during the morning hours (9 a.m. to 12 noon) and subsequently during the late evening or early morning hours (11 p.m. to 3 a.m.). Blood samples were collected in heparinized tubes at the mid-point of each clearance period by means of an indwelling 17 gauge needle. Every attempt was made to avoid psychic or physical trauma to the patient and no 
DIURNAL VARIATION IN RENAL FUNCTION IN CIRRHOSIS

TABLE III

Summary of literature: renal hemodynamics in cirrhosis and ascites

\begin{tabular}{|c|c|c|c|}
\hline Investigator & $\begin{array}{l}\text { Number } \\
\text { of } \\
\text { Patients }\end{array}$ & $\begin{array}{c}\text { Glomerular Filtration } \\
\text { Rate } \\
\text { (cc./min.) }\end{array}$ & $\begin{array}{l}\text { Effective Renal } \\
\text { Plasma Flow } \\
\text { (cc./min.) }\end{array}$ \\
\hline $\begin{array}{l}\text { Patek et al * (23) } \\
(1948)\end{array}$ & 3 & $\begin{array}{l}135 *+ \\
(91-172)\end{array}$ & $\begin{array}{c}581 t \\
(434-709)\end{array}$ \\
\hline $\begin{array}{l}\text { Farnsworth } \\
\text { and Krakusin } \\
\text { (1948) }\end{array}$ & 2 & $\begin{array}{l}68 * t \\
(61-74)\end{array}$ & $\begin{array}{c}446 \ddagger \\
(415-476)\end{array}$ \\
\hline $\begin{array}{l}\text { Losl1e } \\
(1949)\end{array}$ & 5 & $69 * t$ & $371 \neq$ \\
\hline $\begin{array}{l}\text { Goodyer ot al } \\
(1950)\end{array}$ & 6 & $\frac{120 * *+}{(60-124)}$ & $\begin{array}{c}471 t \\
\left(298^{t}-647\right)\end{array}$ \\
\hline
\end{tabular}

* Inulén clearanco

* Mannitol clearance

t Corrected to $1.73 \mathrm{~m}^{2}$.

I Uncorrected data

Note: Max. and min. values appear in parenthesis.

additional venapunctures or urethral instrumentation were performed after the experiment had begun. Inulin was determined by Harrison's (30) modification of the method of Alving, Rubin, and Miller (31). Para-aminohippurate was determined by the method of Smith and associates (32) as described by Goldring and Chasis (33).

Measurements of extracellular volume (employing a continuous infusion of mannitol over eight hours) were usually made concurrently with the day time clearance periods. Since the mannitol infusions produced a mild diuresis and as such affected urine flow values and inulin
$U / P$ ratios, these data were omitted in a consideration of diurnal variations in renal function. At plasma levels (50-150 mg. \%) used to measure extracellular volume, mannitol is known to have no affect on either filtration rate or renal plasma flow $(33,34)$.

\section{RESULTS}

Table V summarizes day, night, and 24 hour GFR data in normal and cirrhotic subjects. Four out of the five normal subjects showed a definite

TABLE IV

Estimated severity of liver disease in patients studied for diurnal variations in renal hemodynamics

\begin{tabular}{|c|c|c|c|c|}
\hline \multirow[b]{2}{*}{ Pationt } & \multirow[b]{2}{*}{ Age } & \multicolumn{3}{|c|}{ Severity of Liver Dysfunction } \\
\hline & & $\begin{array}{l}\text { Number of * } \\
\text { Adnissions }\end{array}$ & $\begin{array}{l}\text { History of } \\
\text { Jaundice }\end{array}$ & $\begin{array}{l}\text { Degree of } \\
\text { Ascites }\end{array}$ \\
\hline 1. J. S. & 61 & 3 & Yes & $H$ \\
\hline 2. v. G. & 53 & 2 & Yes & $t$ \\
\hline 3. N. N. & 49 & 3 & Yes & $H H$ \\
\hline 4. J. K. & 40 & 2 & Yes & $H$ \\
\hline 5. C. R. & 57 & 3 & No & $t$ \\
\hline 6. C. R. & 53 & 2 & Yes & $H$ \\
\hline 7. C. N. & 42 & 2 & Yes & $t$ \\
\hline 8. W. B. & 42 & 2 & Yes & $H$ \\
\hline
\end{tabular}


TABLE $\nabla$

Diurnal variations in glomerular filtration rates in normal subjects and in cases of cirrhosis with ascites

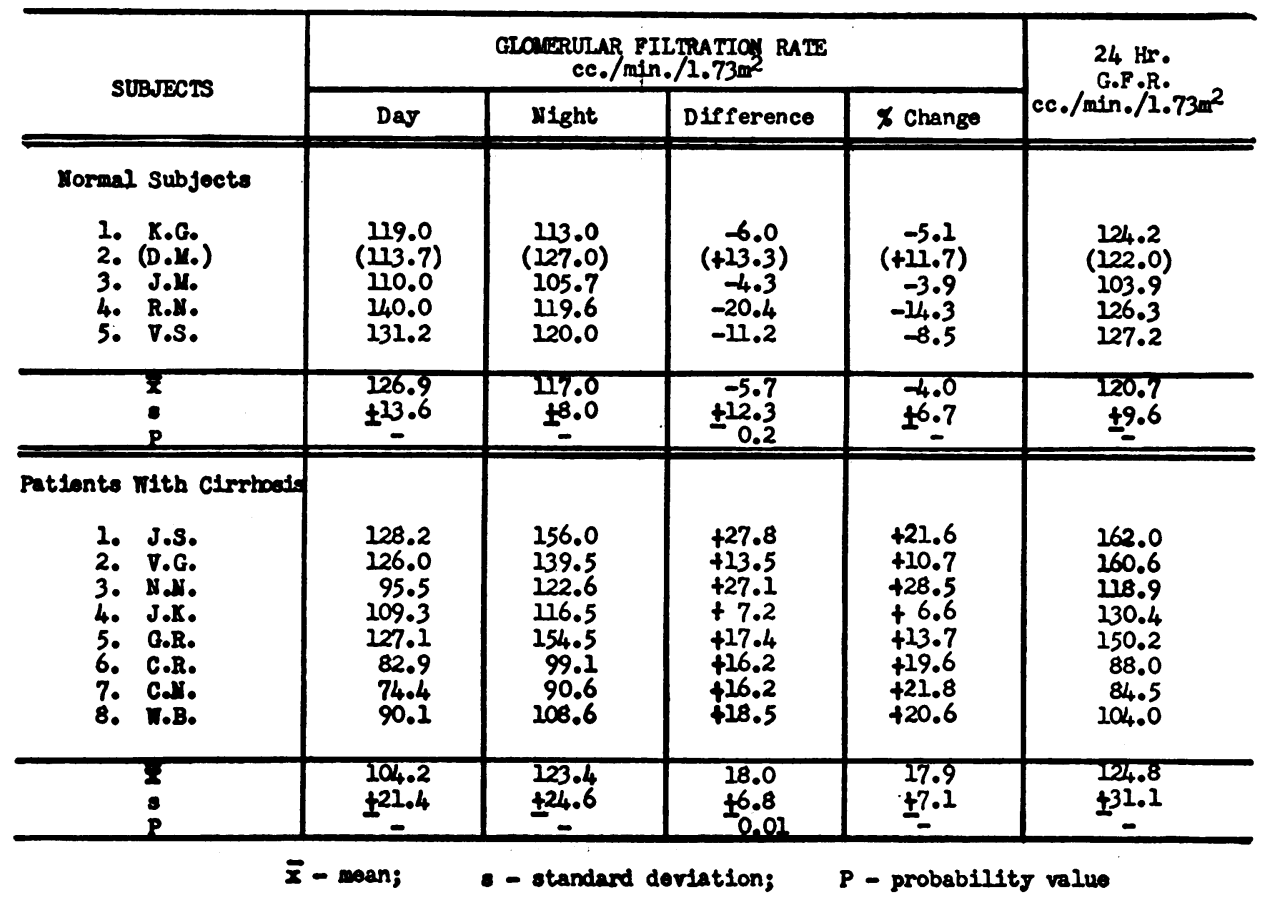

TABLE VI

Diurnal variations in effective renal plasma flow in normal subjects and in cases of cirrhosis with ascites

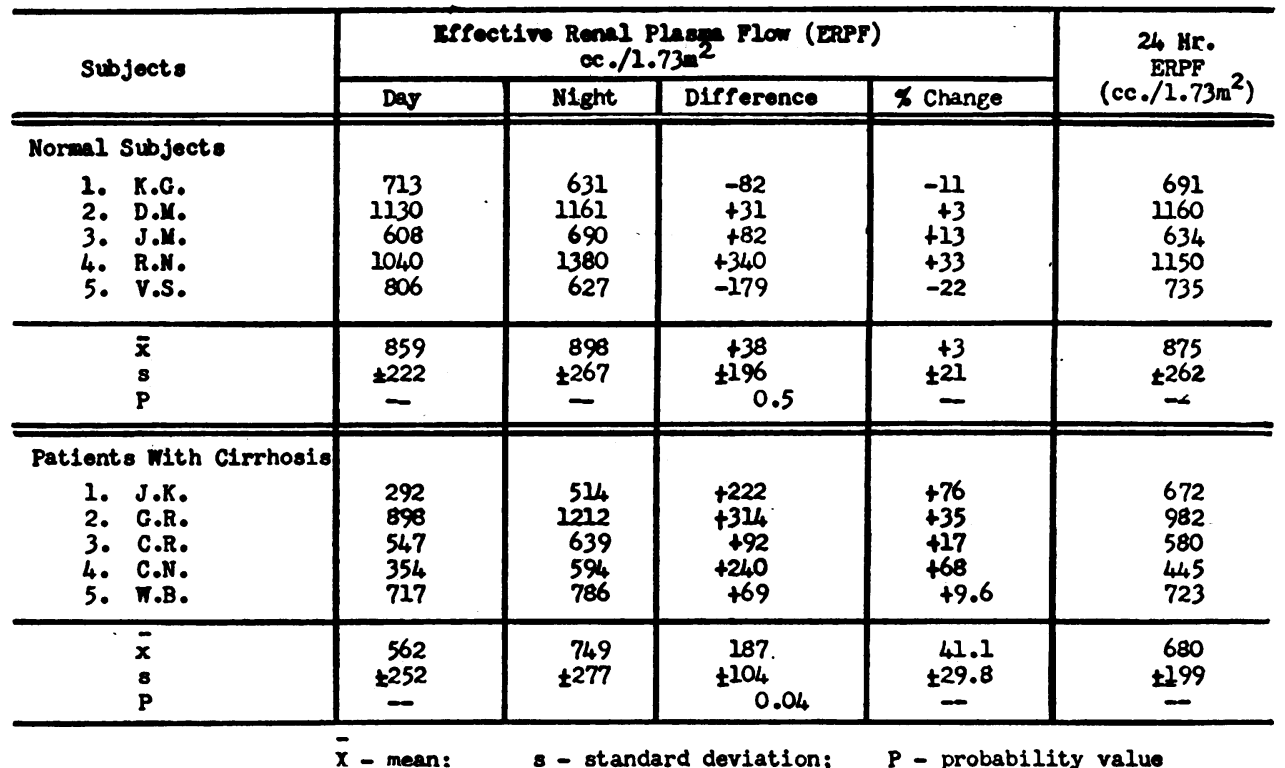


DIURNAL VARIATION IN RENAL FUNCTION IN CIRRHOSIS

TABLE VII

Diurnal variations in fltration fraction in normal subjects and in cases of cirrhosis with ascites

\begin{tabular}{|c|c|c|c|c|c|}
\hline \multirow{2}{*}{ Subjects } & \multicolumn{4}{|c|}{$\begin{array}{c}\text { Filtration Fraction } \\
\left(\mathrm{C}_{1 / \text { CPAH }}\right)\end{array}$} & \multirow[t]{2}{*}{$\begin{array}{c}24 \mathrm{Hr} \\
\mathrm{F} . \mathrm{F} .\end{array}$} \\
\hline & Day & Night & Difference & \& Change & \\
\hline $\begin{array}{l}\text { Normal Subject. } \\
\text { 1. K.G. } \\
\text { 2. D.M. } \\
\text { 3. J.M. } \\
\text { 4. R.N. } \\
\text { 5. V.S. }\end{array}$ & $\begin{array}{l}16.6 \\
10.1 \\
18.1 \\
13.5 \\
16.3\end{array}$ & $\begin{array}{r}17.8 \\
10.8 \\
15.4 \\
8.7 \\
19.1\end{array}$ & $\begin{array}{l}+1.2 \\
+0.7 \\
-2.7 \\
-4.8 \\
+2.8\end{array}$ & $\begin{array}{r}+7 \\
+1 \\
-15 \\
-35 \\
+17\end{array}$ & $\begin{array}{l}17.9 \\
10.3 \\
16.7 \\
10.9 \\
17.3\end{array}$ \\
\hline $\begin{array}{l}\bar{x} \\
\text { s }\end{array}$ & $\begin{array}{r}u_{4} .9 \\
+3.1\end{array}$ & $\begin{array}{l}13.3 \\
14.4\end{array}$ & $\begin{array}{l}-0.5 \\
+2.8\end{array}$ & $\begin{array}{r}-3.0 \\
\pm 20.0\end{array}$ & $\begin{array}{r}14.6 \\
\pm 3.6\end{array}$ \\
\hline $\begin{array}{l}\text { Pationts with } \\
\text { C1rrhosis } \\
\text { 1. J.K. } \\
\text { 2. G.R. } \\
\text { 3. C.R. } \\
\text { 4. C.R. } \\
\text { 5. W.B. }\end{array}$ & $\begin{array}{l}37.4 \\
14.2 \\
15.2 \\
21.0 \\
12.6\end{array}$ & $\begin{array}{l}22.4 \\
12.8 \\
15.5 \\
15.3 \\
13.8\end{array}$ & $\begin{array}{r}-15.4 \\
-1.4 \\
+0.3 \\
-5.7 \\
+1.2\end{array}$ & $\begin{array}{c}-42 \\
-9 \\
+2 \\
-27 \\
+9.5\end{array}$ & $\begin{array}{l}19.4 \\
15.3 \\
15.1 \\
19.0 \\
14.04\end{array}$ \\
\hline $\begin{array}{l}\bar{x} \\
8 \\
p\end{array}$ & $\begin{array}{r}20.1 \\
+10.2 \\
-\end{array}$ & $\begin{array}{r}16.0 \\
+3.8 \\
-\end{array}$ & $\begin{array}{r}-4.2 \\
\pm 7.0 \\
0.2\end{array}$ & $\begin{array}{l}-13.3 \\
\pm 21.1 \\
-\end{array}$ & $\begin{array}{l}16.6 \\
\pm 2.4 \\
-\end{array}$ \\
\hline
\end{tabular}

tendency toward a decreased GFR during the night. However, the mean day-night difference was not statistically significant. All of the cirrhotic patients showed a nocturnal increase in GFR. The night values averaged $123.4 \pm 24.6$ cc./min. whereas the mean for the day period was $104.2 \pm 21.4 \mathrm{cc} . / \mathrm{min}$. The mean difference of $18.0 \mathrm{cc} . / \mathrm{min}$. was highly significant with a $\mathrm{P}$ value of less than 0.01 .

Data on diurnal variations in ERPF are shown in Table VI. In normal subjects there was no consistent change in nocturnal ERPF. Three out of five subjects showed a moderate increase whereas two showed a decrease in ERPF during the night. In striking contrast, all five of the cirrhotic patients infused with $\mathrm{PAH}$ showed a significant nocturnal increase in ERPF with a mean increase of $187 \pm 104 \mathrm{cc} . / \mathrm{min}$. $(P=0.04)$.

Filtration fractions (FF) in normal and cirrhotic subjects are presented in Table VII. In normal subjects there was no consistent diurnal change in FF. Although the mean difference between the day and night FF in cirrhotic subjects was not statistically significant, it should be noted that there was a marked nocturnal fall in FF in two patients in whom the day FF values were ab- normally high. On the average there was a tendency for a nocturnal decrease in FF in cirrhotic patients.

Data comparing 24 hour clearance values with those obtained during spot clearance periods are shown in Tables V, VI, and VII. In normal subjects, the 24 hour GFR calculated from the 24 hour clearance of inulin averaged $120.7 \pm 9.6 \mathrm{cc}$./ min., a value which fell between the day and night clearances. In cirrhotic subjects, the mean 24 hour GFR of $124.8 \pm 31.1 \mathrm{cc}$. $/ \mathrm{min}$. was actually greater than either the average day or night values. In normal subjects the 24 hour ERPF and FF values fell between those of the day and night clearance periods, whereas in cirrhotic patients these data more closely approximated those of the night clearance periods.

\section{DISCUSSION}

In normal subjects there was a tendency toward a nocturnal decrease in GFR without consistent changes in ERPF. These findings agree with those reported by Sirota, Baldwin; and Villarreal (11). In contrast to the findings in normal subjects, patients with cirrhosis and ascites showed a significant nocturnal increase in GFR and ERPF. 
Both the normal subjects and cirrhotic patients were allowed food and water ad libitum during the renal tests. It has been shown that variations in urine flow by the administration of water with resultant flows of $1.0 \mathrm{up}$ to $12.0 \mathrm{cc}$. $/ \mathrm{min}$. had no effect on renal hemodynamics (35), and as such would rule against any influences due to the ingestion of fluids during the waking hours. All patients were maintained on high protein, high carbohydrate, low fat diets. High protein diets have been shown to increase filtration rate and renal plasma flow when fed over a 102 day period in normal subjects (36). Little information is available in the literature on the acute effects of meals on renal hemodynamics. A large beef steak meal as compared with a light breakfast was reported to have no effect on the renal plasma flow in one subject although it slightly increased the filtration rate (37). The nocturnal reversal in diurnal rhythm in cirrhotic patients would thus not seem to be related to either food or water intake during the waking hours.

The reversal of diurnal rhythm in renal hemodynamics observed in our patients with cirrhosis and ascites was similar to that reported by Baldwin, Sirota, and Villarreal $(21)$ and $\operatorname{Brod}(10,20)$ in patients with congestive heart failure. Brod and Fejfar (20) noted that the spontaneous nocturnal diuresis of cardiac patients was always accompanied by an increase in ERPF and a fall in filtration fraction. In our series of cirrhotic patients, those with abnormally high day FF values showed a similar nocturnal fall in FF. Brod and Fejfar theorized that the nocturnal improvement in renal blood flow was the result of redistribution of body water and blood flow in association with a decreased metabolic demand by muscles and viscera during the night hours.

Goldman (26) recently reported a nocturnal diuresis and natriuresis in patients with cirrhosis of the liver and ascites, in cases of congestive heart failure, and in two out of five patients with degenerative glomerulonephritis. He postulated that the nocturnal natriuresis might depend on variations in tubular metabolism controlled by a humoral agent which perhaps would be affected by the functional state of the liver.

Antidiuretic substances have previously been reported in the urine of some patients with congestive heart failure (38), cirrhosis (39), acute hepatitis (40), nephrotic edema (41), and hypertension (42). Although a diurnal variation in the secretion of $\mathrm{ADH}$ by the posterior pituitary could account for the nocturia in these conditions, it would fail to explain the changes in glomerular filtration rate and renal plasma flow. It has been reported that the infusion of physiologic doses of pitressin had no significant effect on renal hemodynamics in man (43).

Farnsworth and Krakusin (25) noted that in both cirrhosis with ascites and in congestive heart failure, the kidneys behaved as if the body were dehydrated. They submitted the hypothesis that a specific stimulus to salt and water retention was probably acting in both diseases. Deming and Luetscher (44) have reported an increase in excretion of desoxycorticosterone-like substances in edematous patients with heart failure or nephrosis. Evidence of increased activity of desoxycorticosterone-like hormones also has been reported in cirrhosis (45). In normal dogs, it has been shown that large doses of desoxycorticosterone expand the inulin space (46) and increase filtration rate and renal plasma flow $(46,47)$. It has recently been demonstrated that ACTH may effect an impressive diuresis and natriuresis in cases of nephrosis (48-51). It has been further shown by Rosenbaum, Davis, and Ferguson (52) that nocturnal oliguria and suppression of electrolyte excretion occurring in normal subjects could be eliminated or diminished as a result of cortisone therapy with an actual reversal of the rhythm. Recent work by Gaunt, Birnie and Eversole (53) has led to the theory of a reciprocal or antagonistic action between $\mathrm{ADH}$ and adrenal cortical hormones. It is entirely possible that the reversal of diurnal rhythm in renal function noted in various edematous states may be due to increased adrenal cortical activity during the night hours with relative neutralization of $\mathrm{ADH}$ effects.

In this series of eight patients with cirrhosis and ascites, four showed abnormally low day-time GFR values, whereas the rest showed rates within normal limits. Two of the four cirrhotic patients with depressed day-time filtration rates had 24 hour GFR values which were within normal limits. Two out of five patients showed an impairment in ERPF and an abnormal elevation of filtration fraction. These findings agree with those reported in the literature (22-25). It was difficult to cor- 
relate any impairment of renal function with the severity of the cirrhosis, degree of ascites or with any past history of cardiovascular renal disease.

The importance of 24 hour measurement of glomerular filtration rate and renal plasma flow is pointed up by these studies in normal and cirrhotic subjects. In normal subjects, minimal diurnal variations did not result in significant differences between the 24 hour values and those obtained in spot clearance periods. In cirrhotics, however, spot clearance periods run during the day deviated markedly from 24 hour measurements of glomerular filtration rate and renal plasma flow. The mean 24 hour values in cirrhotic individuals more closely approximated the values obtained during the nocturnal clearance periods. These discrepancies are of particular importance in studies of disturbances in electrolyte excretion in edematous states.

\section{SUM MARY}

1). In a series of cases of cirrhosis with ascites a reversal of diurnal rhythm was noted with a nocturnal increase in glomerular filtration rate and effective renal plasma flow. Those patients with impaired renal flows showed a fall in FF as renal blood flow improved during the night. The possible participation of hormonal factors in the diurnal reversal is discussed.

2). Twenty-four hour measurements of renal hemodynamics were within normal limits in six out of eight patients with cirrhosis and ascites.

$3)$. In patients with marked diurnal variations in renal hemodynamics, spot clearance periods run during the waking hours were appreciably lower than those obtained through the 24 hour clearance period. The importance of this fact in relation to electrolyte balance studies is emphasized.

\section{ACKNOWLEDGMENTS}

The authors are indebted to Dr. Smith Freeman for his helpful criticisms in the planning and execution of these studies. The authors also wish to gratefully acknowledge the support and unfailing interest of Dr. Charles B. Puestow, Chief of the Surgical Services, and Dr. Lyle A. Baker, Chief of the Medical Services at VA Hospital, Hines, Illinois.

\section{REFERENCES}

1. Quincke, H., Ueber den Einfluss des Schlafes auf die Harnabsonderung. Arch. exper. Path. u. Pharmakol., 1877, 7, 115.
2. Campbell, J. A., and Webster, T. A., Day and night urine during complete rest, laboratory routine, light muscular work and oxygen administration. Biochem. J., 1921, 15, 660.

3. Campbell, J. A., and Webster, T. A., Effect of severe muscular work on composition of the urine. Biochem. J., 1922, 16, 106.

4. Kleitman, N., Physiology of sleep. I. The effects of prolonged sleeplessness on man. Am. J. Physiol., 1923, 66, 67.

5. Simpson, G. E., Diurnal variations in the rate of urine excretion for two hour intervals: some associated factors. J. Biol. Chem., 1924, 59, 107.

6. Simpson, G. E., The effect of sleep on urinary chlorides and $\mathrm{pH}$. J. Biol. Chem., 1926, 67, 505.

7. Norn, M., Untersuchungen über das Verhalten des Kaliums in Organismus. II. Uber Schwankungen der Kalium-, Natrium-, and Chloridausecheidung durch die Niere im Laufe des Tages. Skandinav. Arch. f. Physiol., 1929, 55, 184.

8. Manchester, R. C., The diurnal rhythm in water and mineral exchange. J. Clin. Invest., 1933, 12, 995.

9. Gerritzen, F., The rhythmic function of the human liver. Acta med. Scandinav., 1940, Suppl. 108, 121.

10. Brod, J., Klincsky uyznam Filtrace a Resorpee v ledvinch. Cas. lak. ces., 1946, 85, 1315.

11. Sirota, J. H., Baldwin, D. S., and Villarreal, H., Diurnal variations of renal function in man. $J$. Clin. Invest., 1950, 29, 187.

12. Jores, A., Die Urineinschränkung in der Nacht. Deutsches Arch. f. klin. Med., 1933, 175, 244.

13. Gerritzen, F., quoted by Borst, J. G. G., and de Vries, L. A. (14).

14. Borst, J. G. G., and de Vries, L. A., The three types of "natural" diuresis. Lancet, 1950, 2, 1.

15. Joslings, Discussion of Linke, F., Kosmiche und terrestrische Rhythmen. Acta med. Scandinav., 1940, Suppl. 108, 43.

16. Addis, T., Barrett, E., Poo, L. J., Ureen, H. J., and Lippman, R. W., The relation between protein consumption and diurnal variations of the endogenous creatinine clearance in normal individuals. J. Clin. Invest., 1951, 30, 206.

17. Wilson, C., On diurnal and nocturnal excretion of urine. Lancet, 1889, 1, 1299.

18. Quincke, H., Ueber Tag-und Nachtharn. Arch. exper. Path. u. Pharmakol., 1893, 32, 211.

19. Fishberg, A., Hypertension and Nephritis. Lea \& Febiger, Philadelphia, 1939, Ed. 4.

20. Brod, J., and Fejfar, Z., The origin of oedema in heart failure. Quart. J. Med., 1950, 19, 187.

21. Baldwin, D. S., Sirota, J. H., and Villarreal, H., Diurnal variations of renal function in congestive heart failure. Proc. Soc. Exper. Biol. \& Med., 1950, 74, 578.

22. Leslie, S. H., Johnson, B., and Ralli, E. P., Renal clearances in patients with cirrhosis of the liver, with and without ascites. J. Clin. Endocrinol., 1949, 9, 682. 
23. Patek, A. J., Jr., Mankin, H., Colcher, H., Lowell, A., and Earle, D. P., Jr., The effects of intravenous injection of concentrated human serum albumin upon blood plasma ascites, and renal function in three patients with cirrhosis of the liver. J. Clin. Invest., 1948, 27, 135.

24. Goodyer, A. V. N., Relman, A. S., Lawrason, F. D., and Epstein, F. H., Salt retention in cirrhosis of the liver. J. Clin. Invest., 1950, 29, 973.

25. Farnsworth, E. B., and Krakusin, J. S., Electrolyte partition in patients with edema of various origins. J. Lab. \& Clin. Med., 1948, 33, 1545.

26. Goldman, R., Studies in diurnal variation of water and electrolytes: nocturnal diuresis of water and sodium in congestive cardiac failure, cirrhosis of the liver and degenerative glomerulonephritis. J. Clin. Invest., 1951, 30, 642.

27. Smits, J. A., Thesis Amsterdam, quoted by Borst, J. G. G., and de Vries, L. A. (14).

28. Jones, R. A., McDonald, G. O., Bond, E. E., and Last, J. H., Diurnal variations of renal function in cirrhosis. Federation Proc., 1951, 10, 311.

29. Last, J. H., Pitesky, I., and Marbarger, J. P., Applications of nylon catheters in physiology of the circulation. Science, 1950, 112, 719.

30. Harrison, H. E., A modification of the diphenylamine method for determination of inulin. Proc. Soc. Exper. Biol. \& Med., 1942, 49, 111.

31. Alving, A. S., Rubin, J., and Miller, B. F., A direct colorimetric method for the determination of inulin in blood and urine. J. Biol. Chem., 1939, 127, 609.

32. Smith, H. W., Finkelstein, N., Aliminosa, L., Crawford, B., and Graber, M., The renal clearances of substituted hippuric acid derivatives and other aromatic acids in dog and man. J. Clin. Invest., 1945, 24, 388.

33. Goldring, W., and Chasis, $\mathrm{H}$., Hypertension and $\mathrm{Hy}-$ pertensive Disease. The Commonwealth Fund, New York, 1944.

34. Lauson, H. D., Bradley, S. E., and Cournand, A., The renal circulation in shock. J. Clin. Invest., 1944, 23, 381.

35. Smith, H. W., The Kidney : Structure and Function in Health and Disease. Oxford Univ. Press., New York, 1951.

36. Pullman, T. N., Alving, A. S., and Landowne, M., Effects of protein in the diet upon certain aspects of renal function. Federation Proc., 1949, 8, 129.

37. White, H. L., and Rolf, D., The effects of exercise and of some other influences on the renal circulation in man. Am. J. Physiol., 1948, 152, 505.

38. Bercu, B. A., Rokaw, S. N., and Massie, E., Antidiuretic action of urine of patients in cardiac failure. Circulation, 1950, 2, 409.
39. Ralli, E. P., Robson, J. S., Clarke, D., and Hoagland, C. L., Factors influencing ascites in patients with cirrhosis of the liver. J. Clin. Invest., 1945, 24, 316.

40. Shorr, E., Hepatorenal vasotropic factors in experimental cirrhosis, in Transactions of the 6th Conf. on Liver Injury. Josiah Macy, Jr. Foundation, New York, 1947, p. 33.

41. Robinson, F. H., Jr., and Farr, L. E., The relation between clinical edema and the excretion of an antidiuretic substance in the urine. Ann. Int. Med., 1940, 14, 42.

42. Grollman, A., and Woods, B., A new procedure for the determination of the antidiuretic principle in urine. Endocrinology, 1949, 44, 409.

43. Maxwell, M. H., and Breen, E. S., quoted by Smith, H. W. (35), p. 432.

44. Deming, Q. B., and Luetscher, J. A., Jr., Bioassay of desoxycorticosterone-like material in urine. Proc. Soc. Exper. Biol. \& Med., 1950, 73, 171.

45. Eisenmenger, W. J., Blondheim, S. H., Bongiovanni, A. M., and Kunkel, H. G., Electrolyte studies on patients with cirrhosis of the liver. J. Clin. Invest., 1950, 29, 1491.

46. Gaudino, M., and Levitt, M. F., Influence of the adrenal cortex on body water distribution and renal function. J. Clin. Invest., 1949, 28, 1487.

47. Collings, W. D., Downing, C. F., and Hodges, R. E., Renal clearances in normal dogs receiving desoxycorticosterone acetate. Federation Proc., 1949, 8, 27.

48. Farnsworth, E. B., Acute and subacute glomerulonephritis modified by adrenocorticotropin. Proc. Soc. Exper. Biol. \& Med., 1950, 74, 57.

49. Farnsworth, E. B., Metabolic changes associated with administration of adrenocorticotropin in the nephrotic syndrome. Proc. Soc. Exper. Biol. \& Med., 1950, 74, 60.

50. Luetscher, J. A., Jr., Deming, Q. B., and Johnson, B. B., A comparison of the effects of ACTH and cortisone in nephrosis. J. Clin. Invest., 1951, 30, 658.

51. Barnett, H. L., Forman, C. W., McNamara, H., McCrory, W. W., Rapoport, M., Michie, A. J., and Barbero, G., The effect of adrenocorticotrophic hormone on children with the nephrotic syndrome. II. Physiologic observations on discrete kidney functions and plasma volume. J. Clin. Invest., 1951, $30,227$.

52. Rosenbaum, J. D., Davis, R. K., and Ferguson, B. C., The influence of cortisone on water diuresis in man. J. Clin. Invest., 1951, 30, 668.

53. Gaunt, R., Birnie, J. H., and Eversole, W. J., Adrenal cortex and water metabolism. Physiol. Rev., 1949, 29, 281. 